\title{
Revised Magnetostratigraphies Confirm Low Sedimentation Rates in Arctic Ocean Cores
}

\author{
WiLliam K. Witte and DenNis V. Kent \\ Lamont-Doherty Geological Observatory and Department of Geological Sciences, Columbia University, \\ Palisades, New' York 10964
}

Received June 11, 1987

\begin{abstract}
The general lack of an age-diagnostic biostratigraphy in the Neogene sediments of the abyssal Arctic Ocean has emphasized the importance of magnetostratigraphy in providing chronostratigraphic control in these sediments. Sedimentation rates interpreted from early magnetostratigraphic studies of cores taken from the T3 ice island in the western Mendeleev Plain were estimated to be on the order of $1 \mathrm{~mm} / 10^{3} \mathrm{yr}$; however, recent amino acid epimerization studies of a core from the same area have suggested sedimentation rates of almost $15 \mathrm{~mm} / 10^{3} \mathrm{yr}$. This controversy has led us to reexamine the paleomagnetism of several of these cores. Our alternating field demagnetization studies indicate that many of these cores have an intense, high coercivity overprint, acquired after the core was opened, that is adequately removed only after treatment at 20 to $70 \mathrm{mT}$. We have remeasured samples from two cores after demagnetizations up to $80 \mathrm{mT}$ and can confirm the position of the Brunhes/Matuyama boundary originally identified in the cores. In addition, the Jaramillo and Olduvai subchrons are identified. Average sedimentation rates in these two cores are 2-3 $\mathrm{mm} / 10^{3} \mathrm{yr}$, similar to the original estimates based on reversal stratigraphy, as well as those determined from recent radiocarbon studies, but incompatible with the amino acid-based dates. (c) 1988 University of Washington.
\end{abstract}

\section{INTRODUCTION}

The chronostratigraphy of the Neogene sediments of the abyssal Arctic Ocean is poorly understood due to the general lack of an age diagnostic biostratigraphy. On the western margin of the Mendeleev Plain in the Canada Basin magnetostratigraphic studies of cores collected at depths of approximately $2850 \mathrm{~m}$ from ice station T3 sites seemed to indicate low sedimentation rates on the order of 1.0 to $3.0 \mathrm{~mm} / 10^{3} \mathrm{yr}$ (Clark, 1970; Hunkins et al., 1971; Clark et al., 1980, 1984), consistent with the magnetostratigraphy reported earlier by Lin'kova (1965) at Station 6 from the vicinity of the Lomonosov Ridge (Fig. 1). However, Sejrup et al. (1984) argued that the available paleomagnetic data from the $\mathrm{T} 3$ cores were unacceptably contaminated with unexplained noise which, combined with the lack of documentation of the alternating field (AF) demagnetization behavior of samples, made it difficult to judge the reliability of the reported results. Sejrup et al.
(1984) concluded that the magnetostratigraphies of available Arctic Ocean cores were not sufficiently well understood to exclude more rapid sedimentation rates and suggested sedimentation rates on the order of $15 \mathrm{~mm} / 10^{3} \mathrm{yr}$ for core T3-67-11 based on their amino acid epimerization studies. More recently, Aksu (1985) and Aksu and Mudie (1985) interpreted paleomagnetic and palynological data from CESAR cores collected from the physiographically distinct Alpha Ridge, approximately $1000 \mathrm{~km}$ north of the T3 cores and at water depths of about $1500 \mathrm{~m}$ (Fig. 1), to indicate low sedimentation rates of 1.0 to $1.5 \mathrm{~mm} / 10^{3} \mathrm{yr}$ for the past 4.25 myr. Amino acid epimerization analyses of foraminifera from the CESAR cores (Macko and Aksu, 1986) also suggested similar sedimentation rates. Although the Alpha Ridge cores come from shallower and morphologically different seafloor, their sedimentation rates compare well with the results of earlier magnetostratigraphic work in the Arctic Ocean as well 


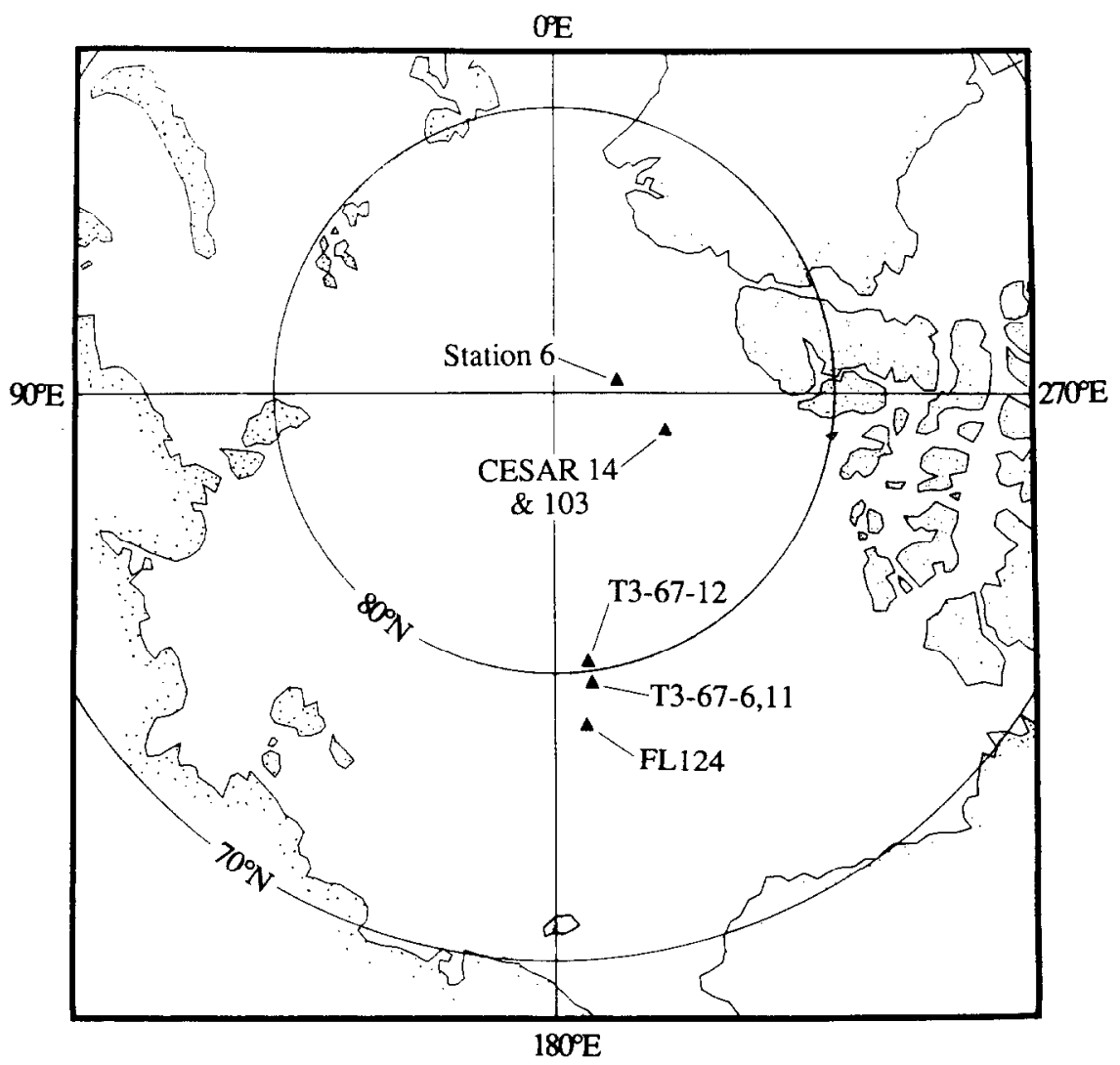

Frg. 1. Sites from which cores discussed in the text were taken. Samples from T3-67-6 and T3-6712 were analyzed in this study.

as radiocarbon constraints on sedimentation rates in the uppermost $5 \mathrm{~cm}$ in core $\mathrm{FL}$ 124 from the Canada Basin (Clark et al., 1986).

Because some questions still remain as to the reliability of the original intepretation of the T3 core magnetostratigraphies, we selected two cores used in the Hunkins et al. (1971) study for remeasurement. We hoped to answer three questions in the course of this study: Is the published interpretation of slow sedimentation in the deep Canada Basin correct? What are the sources of noise in the data and how can they be minimized? If the noise were reduced can further useful details of the magnetostratigraphic record be extracted from the cores?
DATA

Unfortunately, too little of core T3-67-11 remains with known orientation to produce a continuous polarity record. Based on availability of reliable material, two nearby cores were selected for more detailed study: T3-67-6 from $2815 \mathrm{~m}$ at $79^{\circ} 44^{\prime} \mathrm{N}$, $173^{\circ} 04^{\prime} \mathrm{W}$ and $\mathrm{T} 3-67-12$ from $2867 \mathrm{~m}$ at $80^{\circ} 21^{\prime} \mathrm{N}, 173^{\circ} 31^{\prime} \mathrm{W}$ (Fig. 1). These cores were included in the study of Hunkins et al. (1971). Core T3-67-6 was cited by these authors as an example of their best data and is one of the few cases (Clark et al., 1984) where the actual magnetic inclination data and details of the demagnetization treatment have been published for cores from the Canada Basin. The paleomagnetics of 
T3-67-12 and most other T3 cores was simply presented as interpretations of normal and reversed polarity. The original paleomagnetic data (Fig. 2) illustrate some of the problems involved in their interpretation.

The Brunhes/Matuyama boundary was picked at $220 \mathrm{~cm}$ in T3-67-6 and at $100 \mathrm{~cm}$ in T3-67-12. There is, however, considerable scatter in the remanent inclinations even after the $5 \mathrm{mT}$ AF demagnetization treatment used in the original study, enough so that the definition of polarity magnetozones is highly uncertain. In contrast, the declination records in both cores are far more coherent than the inclination records. At such high-latitude sites the expected dipole inclination is $\cong \pm 85^{\circ}$ and thus one would expect the declinations to be very scattered, reflecting the relatively small horizontal component of the high-latitude geomagnetic field. Most of the declinations are, in fact, essentially normal to the split face of the core and do not reverse as the inclination reverses.

Most of the samples from T3-67-6 and T3-67-12 used in the Hunkins et al. (1971) study were recovered for remeasurement, although a number of the original samples were missing and additional samples were taken from the cores. New samples comprised approximately $16 \%$ of the samples analyzed in this study. In all cases the samples had volumes of $5-10 \mathrm{~cm}^{3}$ and were measured with a two-axis cryogenic magnetometer after progressive AF demagnetization treatments. The natural remanent magnetization intensities of the samples after $5 \mathrm{mT}$ AF demagnitization were approximately $10^{-2}$ to $10^{-3} \mathrm{amp} / \mathrm{m}$. IRM (isothermal remanent magnetization) experiments show that $95 \%$ of remanence induced at $1.5 \mathrm{~T}$ is achieved by $0.2 \mathrm{~T}$, with a remanent coercivity of about $40 \mathrm{mT}$, suggesting that magnetite is present in the sediment and responsible for part or all of the remanence.

Progressive AF demagnetization shows that a dominant, near-horizontal (i.e., perpendicular to the core axis) magnetization is typically the component first removed (Fig. 3). The horizontal component's maximum coercivity ranges up to $70 \mathrm{mT}$ and is highly variable even among adjacent samples. After the horizontal overprint is removed, the expected steep magnetic vectors are revealed. Further insight into the timing of the acquisition of the horizontal magnetization component is provided by the manner in which the core was opened and stored. The core was taken in a plastic liner and transported to the core library intact. The core was opened and split into halves along an arbitrary plane parallel to the axis of the core and was allowed to dry in two pieces with the split faces upward, in the steeply dipping $\left(\cong 60^{\circ}\right)$ ambient field at Lamont. Analyses of samples taken at the same depth from opposite halves of the core show that the horizontal overprints are antiparallel within the wholecore frame of reference; i.e., these magnetizations are essentially perpendicular to the split faces of the core and parallel to the steep storage field (Fig. 3). These relationships confirm that despite its high stability, the horizontal overprint is of recent origin (post-splitting) and unrelated to the local geomagnetic field in the Arctic.

\section{INTERPRETATION}

The AF demagnetization experiments suggest that the marked constancy in the declinations after $5 \mathrm{mT}$ treatment is caused by this horizontal overprint and that stecp magnetizations, more likely related to a record of geomagnetic polarity, can be recovered with higher demagnetization treatments. This observation is borne out by what we regard as improved polarity records from both cores after treatment at 40-80 mT (Fig. 4). These records now show the expected scatter in declinations and a serial consistency of inclinations (compare Figs. 2 and 4) allowing magnetozones to be identified more confidently and 
T3-67-6

$5 \mathrm{mT}$
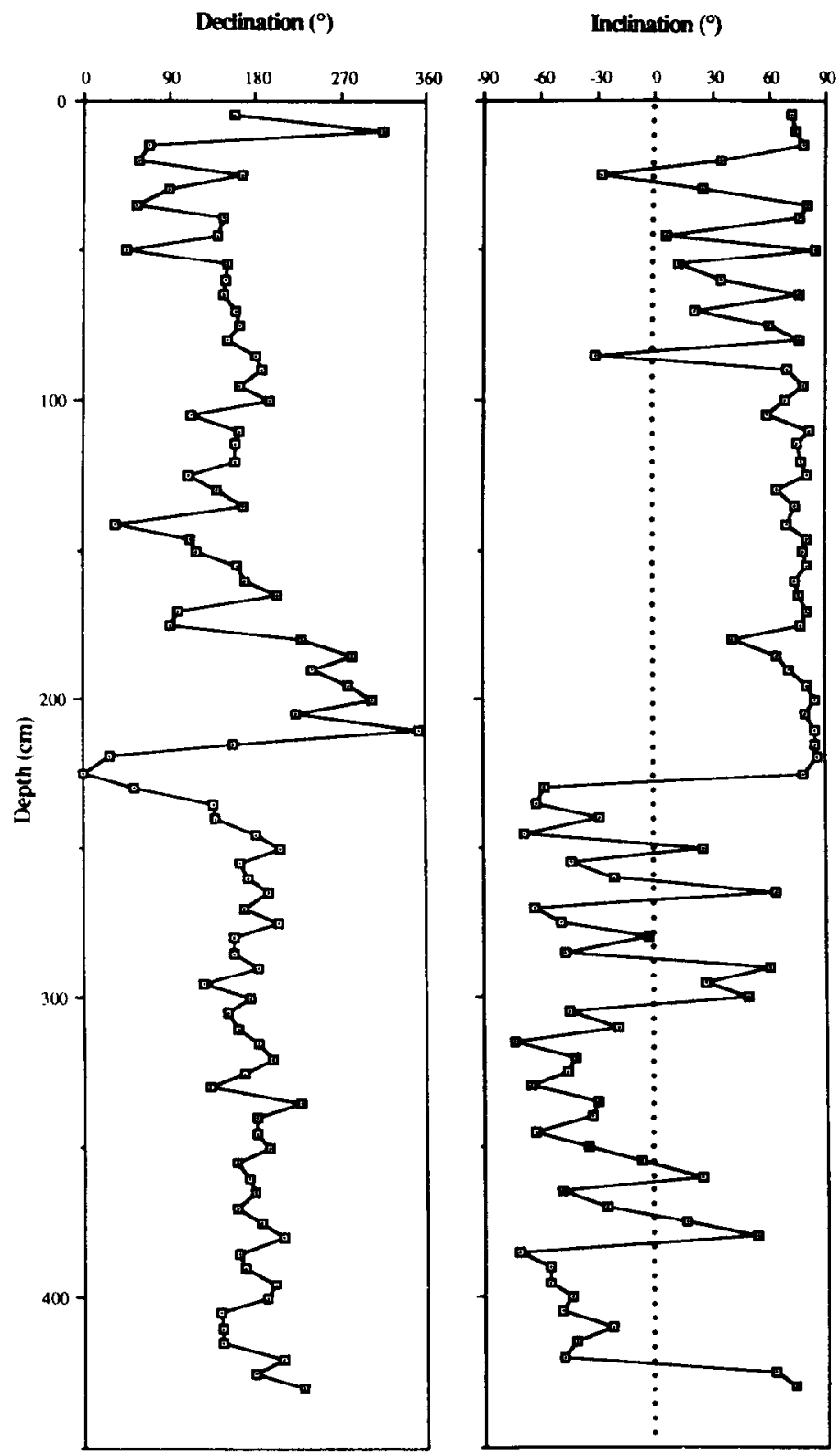

FIG. 2. Remanent magnetization directions after $5 \mathrm{mT}$ demagnctization as determincd by Hunkins et al. (1971). The declination datum was arbitrarily chosen as perpendicular to and zero toward the split face of the "B"' tray core. 


\section{T3-67-12}

$5 \mathrm{mT}$

Dectination ( $\left.{ }^{\circ}\right)$

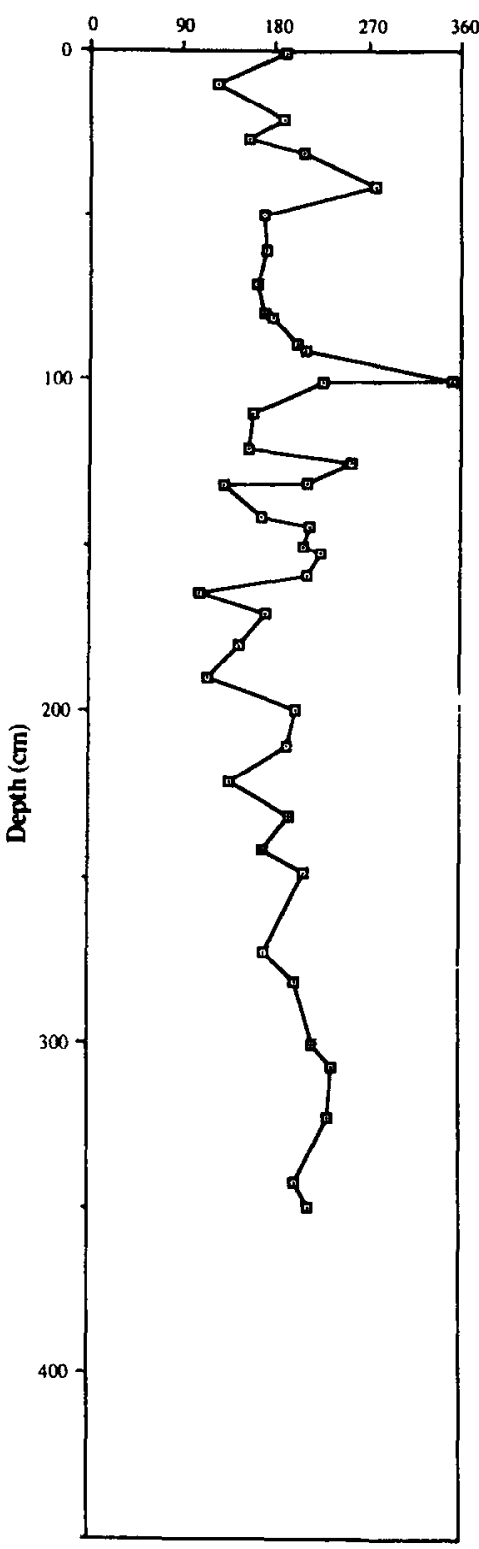

Indination $\left({ }^{\circ}\right)$

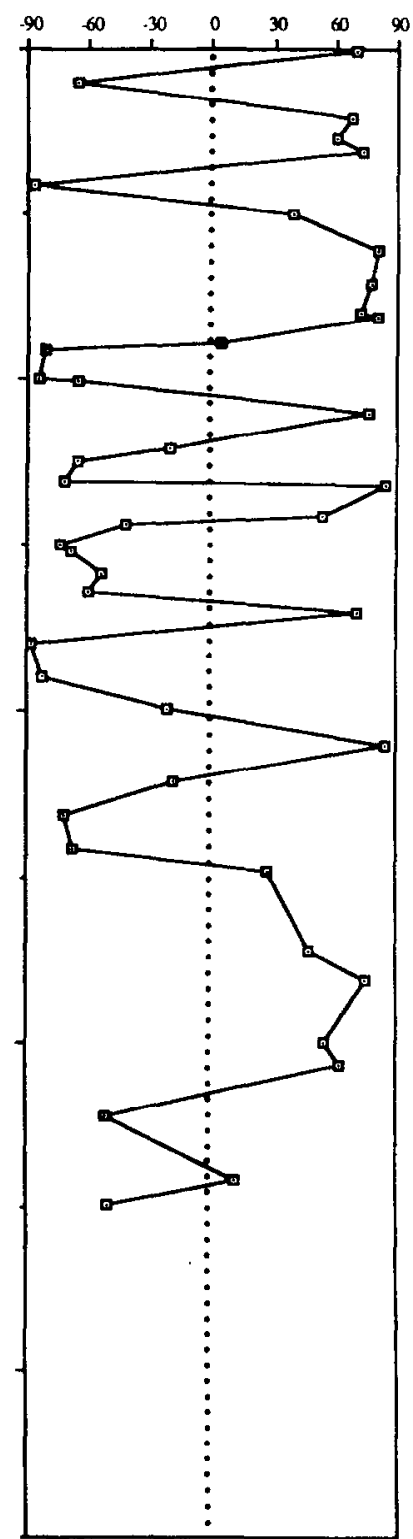

FIG. 2-Continued.

correlated with the geomagnetic polarity time scale.

The changes in polarity at $220 \mathrm{~cm}$ in T3-67-6 and at $100 \mathrm{~cm}$ in T3-67-12 most probably correlate with the Brunhes/Matuyama boundary, the same interpretation (within $10 \mathrm{~cm}$ ) made by Hunkins et al. (1971). The scattered shallow inclinations in the upper $85 \mathrm{~cm}$ of T3-67-6 can be attributed to the sediment disturbance that often occurs near core tops. Further demagnetization and measurement of avail- 


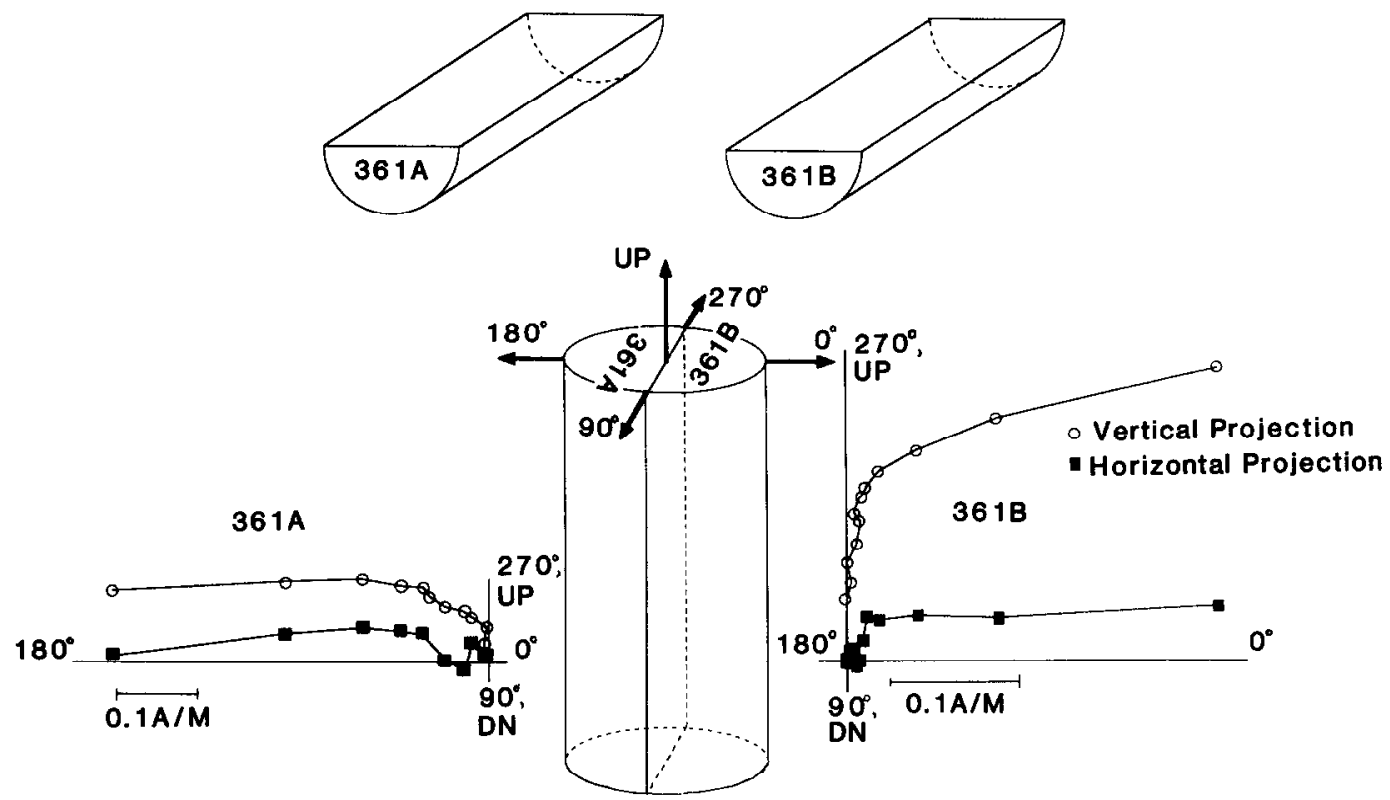

FIG. 3. Progressive AF demagnetization of NRM of samples from opposite halves of core T3-67-6 at $361 \mathrm{~cm}$ depth reveals antiparallel horizontal overprints. Note the recovery of magnetization components with steep negative inclinations after the removal of the horizontal overprints. AF demagnetization steps were NRM, 5, 10, 15, 20, 25, 30, 35, 45. 55, 70, $90 \mathrm{mT}$.

able material from T3-67-11 indicates normal polarity above $132 \mathrm{~cm}$ and mixed reversed and normal polarity as well as intermediate directions from 132 to $231 \mathrm{~cm}$, broadly consistent (within $22 \mathrm{~cm}$ ) with Hunkin's et al. (1971) original interpretation. However, the available sample distribution is too spotty to form a continuous polarity record for T3-67-11.

Below the Brunhes/Matuyama boundary, demagnetization to $80 \mathrm{mT}$ reveals predominately reversely magnetized sediments of the Matuyama with possibly two normal polarity subzones in each core. The short normal polarity interval between 263 and $266 \mathrm{~cm}$ in T3-67-6 is recorded in two adjacent samples and can be correlated to the Jaramillo subchron. A single normal polarity sample occurs at a similar stratigraphic position in T3-67-12; however, the lack of additional material prevented us from taking replicate samples near $129 \mathrm{~cm}$. The interpretation of a normal polarity zone (possibly the Olduvai) at the base of T3-67-06 is also uncertain because only a single sample was available at $430 \mathrm{~cm}$. Nevertheless, T3-67-12 shows a well-defined normal polarity zone between 275 and $310 \mathrm{~cm}$ which most probably correlates with the Olduvai subchron. From $310 \mathrm{~cm}$ to the base at $370 \mathrm{~cm}$, this core is reversely magnetized.

\section{DISCUSSION}

High coercivity overprints, such as those observed in T3-67-6 and T3-67-12, are not usually observed in deep-sea sediments in which characteristic magnetizations are generally isolated with demagnetizing fields less than $15 \mathrm{mT}$ (Opdyke, 1972). However, high coercivity overprints were also noted in CESAR cores from the Alpha Ridge by Aksu (1985) who used demagnetization fields as high as $40 \mathrm{mT}$ to isolate stable directions, and by Løvlie et al. (1986) who used $50 \mathrm{mT}$ AF demagnetization to remove "a dominating magnetic component perpendicular to the sampling surface of the cores." Thus, sediment cores from the Arctic Basin may be particularly suscep- 


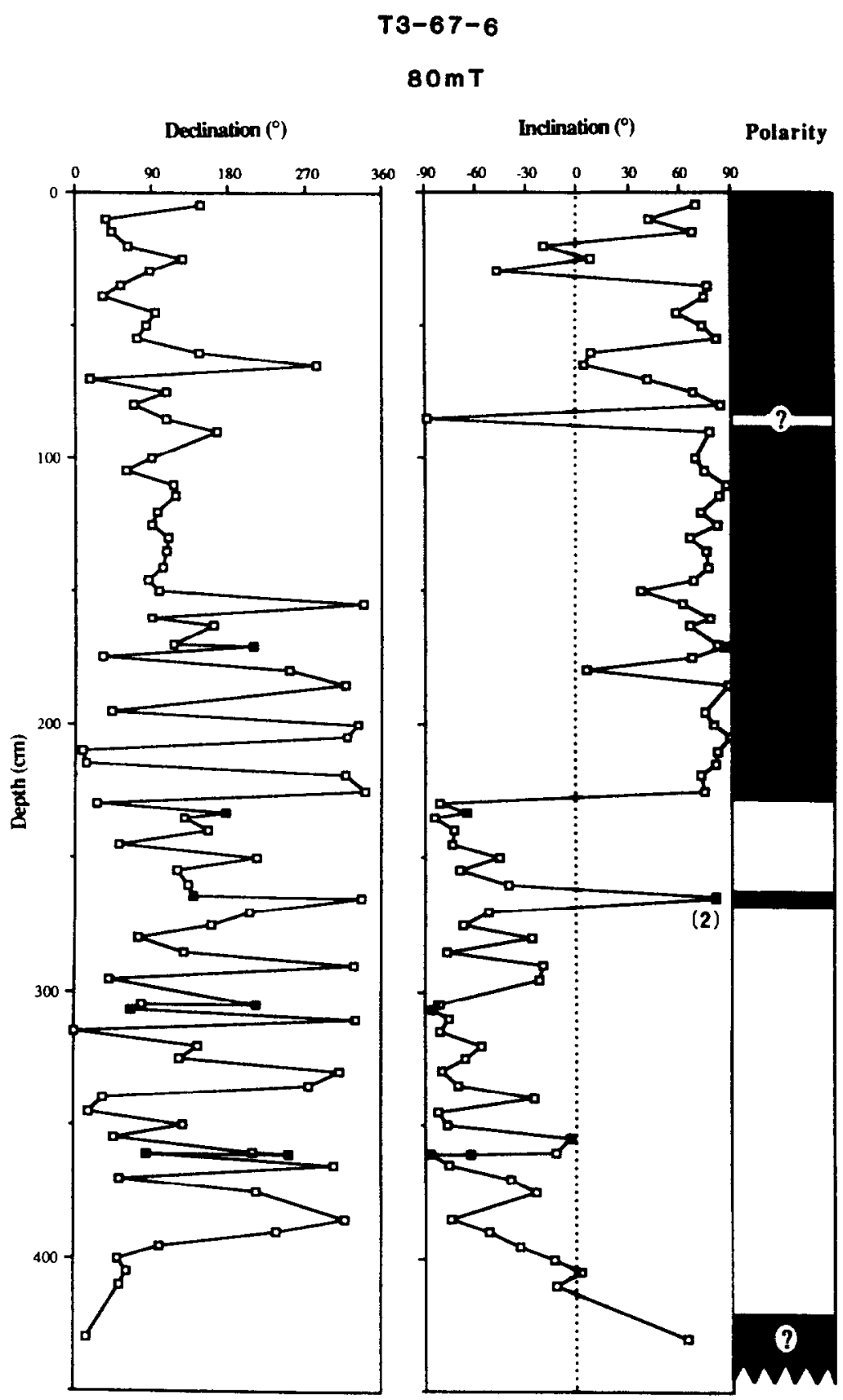

FIG. 4. Remanent magnetization directions after $80 \mathrm{mT}$ demagnetization in cores T3-67-6 and T3-67-12. Solid symbols represent new samples taken to replace missing samples or to fill gaps in the original Hunkins et al. (1971) sample set. The black (normal polarity) and white (reversed polarity) columns indicate our interpretation of the magnetostratigraphy. Polarity intervals interpreted from a single sample are indicated with a question mark; the positive polarity interval in T3-67-6 between 263 and $266 \mathrm{~cm}$ is based on two samples. 


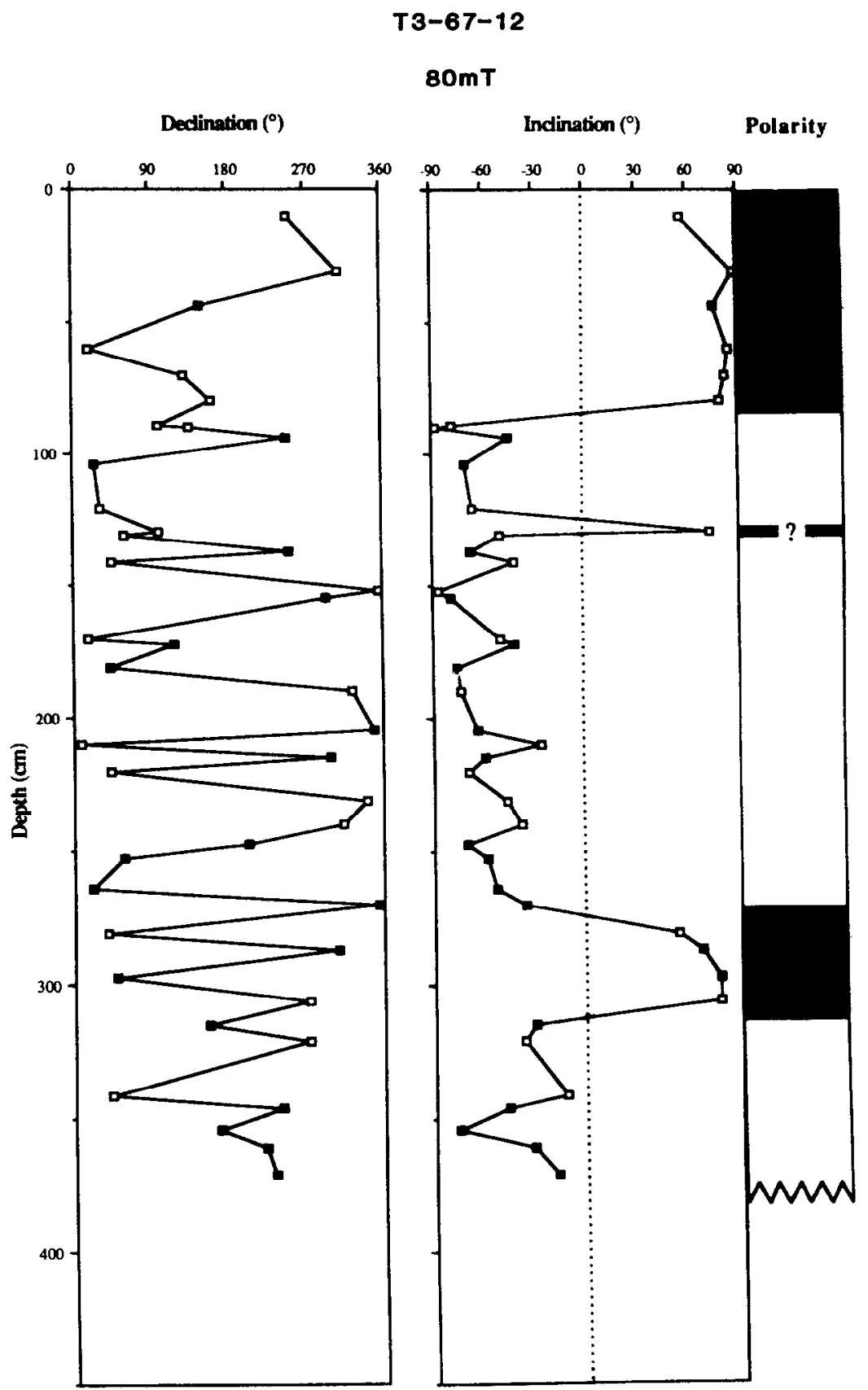

FIG. 4-Continued.

tible to acquisition of stable secondary magnetizations.

Samples from T3-67-6 and T3-67-12 stored in random orientations acquired VRMs (viscous remanent magnetizations) in the laboratory with intensities compa- rable to the intensity of the stable remanence. These viscous magnetizations are easily removed with a 5 to $20 \mathrm{mT}$ AF treatment, which typically affects the horizontal overprint little if at all. Presumably the cores were not exposed to fields much in 
excess of the present $0.05 \mathrm{mT}$ ambient laboratory field during storage, so the generation of a high coercivity overprint observed in the $\mathrm{T} 3$ cores may be related to the physical and chemical changes that take place in a core after it is exposed to the atmosphere and dries (Johnson et al., 1975). If a similar mechanism is responsible for overprints in the CESAR cores, the overprinting process must occur in the early stages of drying because the CESAR cores were measured while still wet (Aksu, 1985).

Based on correlations to the geomagnetic timescale, an interpretation of sedimentation rates in the two cores is possible (Fig. 5 and Table 1). The sedimentation rate we have determined for T3-67-12 is $1.2 \mathrm{~mm} / 10^{3}$ $\mathrm{yr}$ during the Brunhes and $2.0 \mathrm{~mm} / 10^{3} \mathrm{yr}$ from the Brunhes/Matuyama boundary to the base of the Olduvai, with an extrapolated age of $2.2 \mathrm{myr}$ for the base of the core. We cannot exclude the possibility that the lower sedimentation rate for the Brunhes in T3-67-12 is due to the loss of a portion of the uppermost sedimentary section during coring. Core T3-67-6 has a more rapid and uniform sedimentation rate of about $2.8 \mathrm{~mm} / 10^{3} \mathrm{yr}$ from the Jaramillo to the top of the core. The extrapolated age (1.5 myr) for the base of T3-67-6 indicates that the core penetrated close to the expected level of the Olduvai subchronozone; thus, the one unreplicated positive inclination sample from the base of T3-67-6

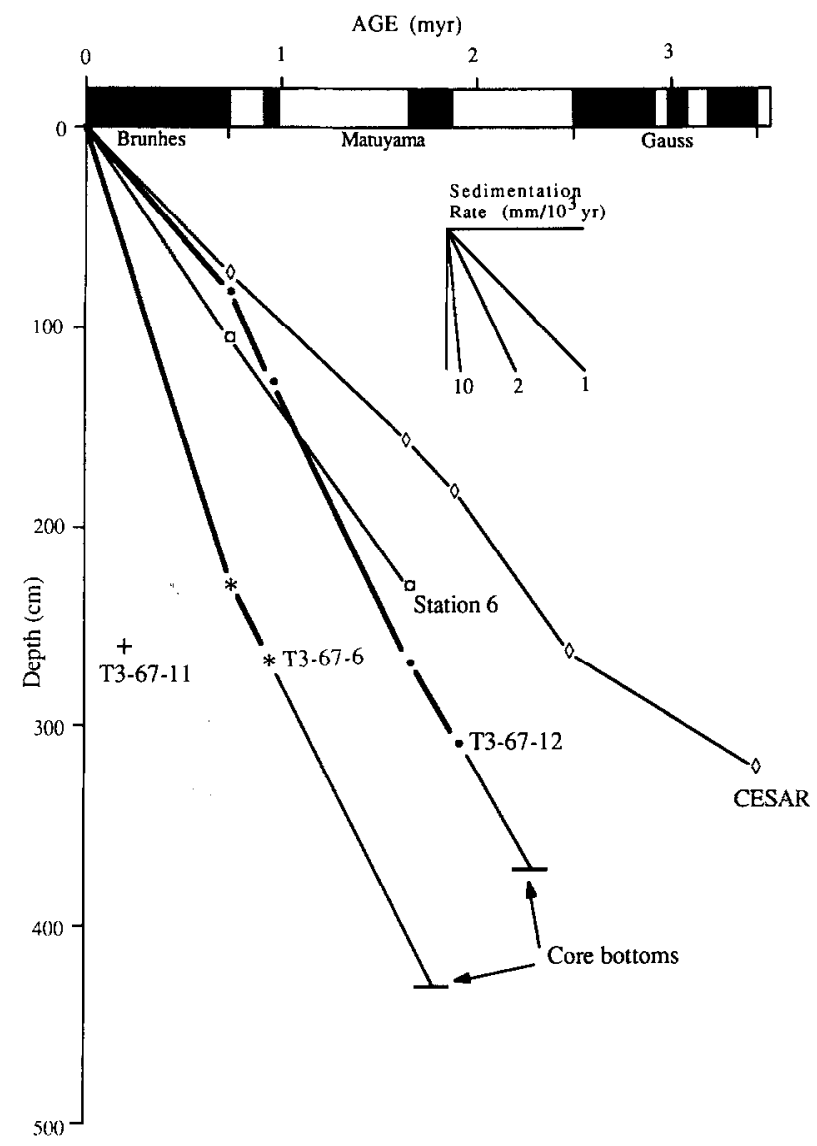

FIG. 5. Sediment depth versus inferred age in T3-67-6 and T3-67-12 compared with magnetostratigraphies from Station 6 of Lin'kova (1965) and CESAR cores 14 and 103 (Aksu. 1985). The age estimate for the $260-\mathrm{cm}$ level in T3-67-11 of $188,000 \mathrm{yr}$ is from the amino acid studies of Sejrup (1984). The geomagnetic polarity time scale is that of Berggren et al. (1985). 
TABLE 1. MAgnetic Polarity Boundaries

\begin{tabular}{lccc}
\hline & \multicolumn{2}{c}{ Depth in core (cm) } & Age \\
\cline { 2 - 3 } Transition & T3-67-6 & T3-67-12 & $\left(10^{3}\right.$ yr $)$ \\
\hline $\begin{array}{c}\text { Brunhes/ } \\
\text { Matuyama } \\
\begin{array}{c}\text { Upper } \\
\text { Jaramillo }\end{array}\end{array}$ & 228 & 85 & 730 \\
$\begin{array}{c}\text { Lower } \\
\text { Jaramillo }\end{array}$ & 268 & 128 & 910 \\
$\begin{array}{c}\text { Upper } \\
\text { Olduvai }\end{array}$ & - & 130 & 980 \\
$\begin{array}{c}\text { Lower } \\
\text { Olduvai }\end{array}$ & - & 311 & 1880 \\
\hline
\end{tabular}

might indeed represent normal polarity. According to magnetostratigraphic correlations, the Pliocene-Pleistocene boundary is placed just younger than the Olduvai subchron at about $1.6 \mathrm{myr}$ (Berggren et al., 1985). Core T3-67-6 therefore encompasses practically the entire Pleistocene in its 430 cm length, whereas core T3-67-12 includes a record of the upper Pliocene and the Pleistocene over its $350 \mathrm{~cm}$. These are minimum estimates for the time represented by the cores, based on the simplest and most reasonable interpretation of polarity. If a significant hiatus were present, the lower normal polarities could correlate with preOlduvai normal polarity chrons and thus the cores could represent a longer interval, but this is judged to be unlikely.

In summary, a reexamination of the magnetostratigraphies of T3-67-6 and T3-67-12 confirms the original interpretation of the position of the Brunhes/Matuyama boundary in these cores by Hunkins et al. (1971). An intense high coercivity overprint, acquired shortly after the cores were opened, dominates the magnetization of both cores, but with sufficient AF demagnetization reliable polarity determinations can be made. Transitional zones between polarity intervals arc not observed in these cores; reversals typically take place in less than $5 \mathrm{~cm}$, which is what one would expect if sedimentation rates are on the order of $1-2 \mathrm{~mm} / 10^{3} \mathrm{yr}$, given geomagnetic transi- tion durations of about $10,000 \mathrm{yr}$. The improved magnetostratigraphic records obtained from T3-67-6 and T3-67-12 strongly suggest that Canada Basin sedimentation rates throughout the Pleistocene are similar to the rates determined for the last 40,000 yr with radiocarbon dating by Clark et al. (1986) and up to an order of magnitude lower than those proposed on the basis of amino acid epimerization studies by Sejrup et al. (1984).

\section{ACKNOWLEDGMENTS}

We thank N. Opdyke for allowing us to use the paleomagnetic data from the original (Hunkins et al., 1971) sludy and W. Broecker, K. Hunkins, and G. Kukla for critical comments on the manuscript. This work was, in part, supported by NSF Grant OCE8400805 . This is LDGO contribution No. 4226.

\section{REFERENCES}

Aksu, A. E. (1985). Paleomagnetic stratigraphy of the CESAR cores. In "Geological Report on CESAR: The Canadian Expedition to Study the Alpha Ridge, Arctic Ocean" (H. R. Jackson, P. J. Mudie and S. M. Blasco, Eds.), pp. 101-114. Geological Society of Canada, Paper 84-22.

Aksu, A. E., and Mudie, P. J. (1985). Magnetostratigraphy and palynology demonstrate at least 4 million years of Arctic Ocean sedimentation. Nature (London) 318, 280-283.

Berggren, W. A., Kent, D. V., Flynn, J. J., and Van Couvering, J. A. (1985). Cenozoic geochronology. Geological Society of America Bulletin 96, 1407-1418.

Clark, D. L. (1970). Magnetic reversals and sedimentation rates in the Arctic Ocean. Geological Society of America Bulletin 81, 3129-3134.

Clark, D. L., Andree, M., Broeker, W. S., Mix, A. C., Bonai, G., Hofman, H. J., Morenzoni, E., Nessi, M., Suter, M., and Woelfli, W. (1986). Arctic Ocean chronology confirmed by accelerator ${ }^{14} \mathrm{C}$ dating. Geophysical Research Letters 13, 319-321.

Clark, D. L., Whitman, R. R., Morgan, K. A., and Mackey, S. D. (1980). Stratigraphy and glacial-marine sediments of the Amerasian Basin, central Arctic Ocean. "Geological Society of America Special Paper No. 181," Geological Society of America, Boulder, CO.

Clark, D. I.., Vincent, J.-S.. Jones, G. A.. and Morris, W. A. (1984). Correlation of marine and continental glacial and interglacial events, Arctic Ocean and Banks Island. Nature (London) 311, 147-149.

Hunkins, K., Bé, A. W. H., Opdyke, N. D., and 
Mathieu, G. (1971). The late Cenozoic history of the Arctic Ocean. In "The Late Cenozoic Glacial Ages"' (K. K. Turekian, Ed.), pp. 215-237. Yale University, New Haven, CT.

Johnson, H. P., Kinoshita, H., and Merrill, R. T. (1975). Rock magnetism and paleomagnetism of some North Pacific deep-sea sediments. Geological Society of America Bulletin 86, 412-420.

Lin'kova, T. I. (1965). Some results of paleomagnetic study of Arctic Ocean floor sediments. Translated from "The Present and Past of the Geomagnetic Field," pp. 279-281. Directorate of Scientific Information Services, DRB Canada.

Løvlie, R., Markussen, B., Sejrup, H. P., and Thiede, J. (1986). Magnetostratigraphy in three Arctic
Ocean sediment cores; Arguments for geomagnetic excursions within oxygen-isotope stage 2-3. Physics of the Earth and Planetary Interiors 43, 173-184.

Macko, S. A., and Aksu, A. E. (1986). Amino acid epimerization in planktonic foraminifera suggests slow sedimentation rates for Alpha Ridge, Arctic Ocean. Nature (London) 322, 730-732.

Opdyke, N. D. (1972). Paleomagnetism of deep-sea O. Reviews of Geophysics and Space physics 10, 213-249.

Sejrup, H. P., Miller, G. H., Brigham-Grette, J., Løvlie, R., and Hopkins, D. (1984). Amino acid epimerization implies rapid sedimentation rates in Arctic Ocean cores. Nature (London) 310, 772-775. 